\title{
The Double Intentionality of Moral Intentional Actions: Scotus and Ockham on Interior and Exterior Acts
}

\author{
Sonja Schierbaum ${ }^{1}$
}

Accepted: 22 February 2021 / Published online: 28 March 2021

(c) The Author(s) 2021

\begin{abstract}
Any account of intentional action has to deal with the problem of how such actions are individuated. Medieval accounts, however, crucially differ from contemporary ones in at least three respects: (i) for medieval authors, individuation is not a matter of description, as it is according to contemporary, 'Anscombian' views; rather, it is a metaphysical matter. (ii) Medieval authors discuss intentional action on the basis of faculty psychology, whereas contemporary accounts are not committed to this kind of psychology. Connected to the use of faculty psychology is (iii) the distinction between interior and exterior acts. Roughly, interior acts are mental as opposed to physical acts, whereas exterior acts are acts of physical powers, such as of moving one's body. Of course, contemporary accounts are not committed to this distinction between two ontologically different kinds of acts. Rather, they might be committed to views consistent with physicalist approaches to the mind. The main interpretative task in this paper is to clarify how Scotus and Ockham explain moral intentional action in terms of the role and involvement of these kinds of acts respectively. I argue that Scotus's account is close to contemporary, 'Anscombian' accounts, whereas Ockham's account is incompatible with them.
\end{abstract}

Keywords Intentional action $\cdot$ Ockham $\cdot$ Scotus $\cdot$ Interior and exterior acts $\cdot$ Double intentionality

\section{Introduction}

My aim in this paper is to present two medieval accounts as a case study of intentional action. Generally, I call 'doing something on account of an end' an intentional action. An action is intentional if the agent acts for a reason. The reason for acting can be deduced from the end on account of which the action is performed. For instance, if Anne is baking a cake in order to cheer Peter up, then her reason for baking is that it is a means to cheering Peter up. In general, acting for a reason implies the ability to intend something as an end and to reason about means-end relations. ${ }^{1}$

A fundamental question that any account of intentional action, whether medieval or contemporary, needs to answer is how intentional actions are individuated. ${ }^{2}$ Medieval accounts, however, differ crucially from contemporary in at least three respects: (i) for medieval authors, individuation is a metaphysical matter. ${ }^{3}$ It is not a matter of description, as it

Sonja Schierbaum

Sonja.Schierbaum@uni-wuerzburg.de

1 Institute of Philosophy, Würzburg University, Josef-Stangl-Platz 2, 97070 Würzburg, Germany is according to contemporary views inspired by Anscombe's work. $^{4}$ (ii) Medieval authors discuss intentional action on the basis of faculty psychology. According to them, the intellect presents ends to the will and deliberates about the means to attain the ends. ${ }^{5}$ Intellect and will are the two powers

${ }_{1}$ Doing a cartwheel or playing the piano can be intentional actions although they do not have any other end beyond themselves. Still, doing a cartwheel is an intentional action in the sense explained only if it is done for a reason. A reason for doing something that does not have an end beyond itself is that it is fun, or good in some sense for the agent. Thus, the reason for an action does not necessarily concern means-end relations. See Alvarez (2010, p. 95).

${ }^{2}$ I do not claim that Ockham and Scotus treat the question of individuation explicitly, or even by using the very term (or its Latin equivalent). I do claim, however, that Ockham and Scotus discuss this question at least implicitly, since they do discuss questions closely related to the

3 As it is in contemporary debates for many philosophers such as Davidson (1963); Goldman (2013); Hornsby (1980); Mackie (2003); Thomson (1971).

4 'Une action est toujours prise 'sous une description', serait la marque propre de l'intentionalité de l'action.” Aucouturier (2018, p. 15). See Anscombe (1981, p. 9).

5 As Hoffmann stresses, strictly speaking, it is not the intellect that deliberates, but the person by means of her intellect, just as it is not the will that wills, but the person by means of her will. Nevertheless, medieval authors often use this language, especially if they discuss the specific contributions of the respective powers to action. See Hoffmann (2020, pp. 5-6). 
of the rational soul, whereas physical powers belong to the sensitive soul. ${ }^{6}$ Any interpretation of medieval approaches as accounts of intentional action has to investigate the different acts of intellect, will, and of physical powers and their interrelation. ${ }^{7}$ Today, this kind of psychology appears rather anachronistic. Therefore, contemporary accounts are not committed to this kind of psychology. Connected to the use of faculty psychology is (iii) the distinction between interior and exterior acts. ${ }^{8}$ Roughly, interior acts are mental, as opposed to physical acts, whereas exterior acts are acts of physical powers, such as of moving one's body. ${ }^{9}$ Again, contemporary accounts are not committed to this distinction of two ontologically different kinds of acts.

Part of the interpreter's job is to render the consequences of the underlying metaphysics for the psychological account of intentional action explicit. The medieval discussion focuses on the question of the morality of actions and their imputability. ${ }^{10}$ Therefore, I present the medieval conceptions of intentional action in the moral context. Also, there is an issue of double intentionality arising in the moral context.

\section{Footnote 2 (continued)}

question of individuation. By the question of individuation, I mean the question what makes an individual thing numerically singular, or what distinguishes it from any other thing. For discussion of individuation, see Lukasiewicz et al. (1953). Scotus and Ockham explicitly discuss questions such as whether an occurring act is still the same or not, in changing circumstances. That is, they discuss the conditions for the identity of acts. Also, in the relevant contexts I discuss, Ockham and Scotus refer to occurring acts in the first place. Thus, their discussion concerns the numerical identity of individuals (see Sects. 3 and 4).

${ }^{6}$ See Ockham, Rep. IV, q. 2 (OTh VII, p. 31); Quaest. In II Sent., q. 20 (OTh VI, pp. 436-440). All references to Ockham are from William of Ockham (1967-1988). See Scotus, Ord. 4, d. 11, q. 3, n. 54 (Vat. IV, p. 436). All references to the Ordinatio of Scotus are from John Duns Scotus (1950-2013).

7 Concerning other topics such as the issue of consciousness, there is a strong tendency among scholars to simply assume that there was a considerable discussion of that issue in the later middle ages. Another widely discussed topic is that of externalist vs. internalist interpretations of epistemological issues, such as for example, Ockham's conception of intuitive cognition. For externalist interpretations, see Schierbaum (2014), King (2015), Lagerlund (2015), Normore (2003); Panaccio (2004, 2010, 2015). For a strong internalist interpretation, see Brower-Toland (2007); for a middle position, see Choi (2016). This general approach can be justified, I think, by the assumption that what is discussed in historical texts is compatible in substance with the issues of contemporary discussions. For further discussion and justification of this approach, see Antognazza (2015); see also Perler (2018).

${ }^{8}$ See Osborne Jr. (2007). For an illuminating overview of this distinction see Müller (2000).

9 I am only giving a rough description here. I discuss this distinction in some detail in the next section.

${ }^{10}$ Valérie Aucouturier criticizes contemporary theories of action for treating the problem of the individuation of action for its own sake, and not as a presupposition for judging them morally. See Aucouturier (2018, p. 18).
My aim is to show that John Duns Scotus and William Ockham account for the moral quality of interior acts by means of double intentionality. The main interpretative task in this paper is to clarify how the two authors explain moral intentional action in terms of the role and involvement of these kinds of acts respectively.

I proceed as follows. First, I present the medieval distinction between interior and exterior acts to set the stage for the issue of the individuation of interior and exterior acts, and hence, for the individuation of intentional action as doing something on account of an end (Sect. 2). The relevant discussion between Scotus and Ockham takes place in the context of moral goodness of acts. Therefore, I present the distinction in the light of the question of the moral quality of interior and exterior acts (Sect. 3). In the discussion of the problem case of changing intention, it should become clear that the authors' disagreement on the moral quality of exterior acts is of crucial importance when it comes to the individuation of exterior acts (Sect. 4). I conclude by pointing out the differences between Scotus's and Ockham's account of moral intentional action (Sect. 5).

\section{Interior and Exterior Acts}

My aim in this section is to clarify the distinction between interior and exterior acts according to Scotus and Ockham. I shall start with Scotus, since, as Ockham's predecessor, he set the agenda, so to speak. ${ }^{11}$ Scotus writes:

Now it is evident that the interior act and the exterior act are distinct in nature. Indeed, these acts are immediately elicited by distinct powers: the interior act by the will, the exterior act by some exterior power, albeit through the will's command. ${ }^{12}$

Interior and exterior acts can be distinguished by means of their causes: they are distinct insofar as their causes are distinct. An interior act is immediately caused by the will, whereas an exterior act is immediately caused by a power

\footnotetext{
11 Ockham follows Scotus in many respects. Therefore, in the presentation of Ockham's account, it seems adequate to focus on the points where Ockham deviates from Scotus. As Hoffmann aptly notes, these deviations can often be described as radicalizations of Scotus's account (and of the accounts of others, like Peter John Olivi). See Hoffmann (2020, p. 158).

12 "Patet autem, quod alia est natura actus interioris et exterioris, imo isti actus eliciuntur immediate a diversis potentiis; interior a voluntate, exterior a potentia aliqua exteriori, licet per imperium voluntatis." Scotus, Quodl. 18, n. 12 (Wadding 12, p. 474). All references to the Quodlibeta of Scotus are from John Duns Scotus (1986). All translations of Scotus's Quodlibet 18, if not indicated otherwise, are those of Thomas Williams. See Williams (2017). (Italics mine).
} 
different from the will, but mediately by the will. ${ }^{13}$ That the will mediately causes an act of another power means that the will immediately causes an act of will which in turn immediately causes another power to cause an act. Metaphysically, the will is a partial cause of its acts. According to both Scotus and Ockham, all acts of will are 'in the power of the will'. If the necessary conditions are satisfied, then the will is able to set itself into operation and elicit some act. The point is that the will is the direct or immediate cause of all and only of its own acts. The will is the mediate cause of acts of other powers insofar as the will can cause these other acts only by means of an act of will.

Interior acts are acts of will, whereas exterior acts are acts of physical powers, i.e., those powers of the soul which are exercised through bodily organs or by parts of the body. If an act of a physical power, such as of moving one's arm, is not mediately caused by the will, it is not an exterior, but a natural act. The difference between exterior and natural acts is that the former acts are voluntary whereas the latter are not. Exterior acts are voluntary insofar as they are 'in the power of the will'. Scotus writes:

In another way, whatever simply is in the power of the will, can be called imputable, although not immediately. And thus, any act of another power which the will can order to be elicited by means of an act of will, [...], is imputable to the will. ${ }^{14}$

Any act of will presupposes at least an act of the intellect as a necessary condition. ${ }^{15}$ In general, one cannot will anything without having some idea of it, although it is of course possible to think about something without willing it. ${ }^{16}$ Unlike the intellect, the will can remain inactive and not produce any act at all with respect to any of its objects,

\footnotetext{
13 That an act is elicited just means that it is caused. See Scotus, Quodl. 18, n. 11 (Wadding 12, p. 482). Ockham conceives of this in a similar way. See Ockham, De connex., q. 8, art. 3 (OTh VIII, p. 374) "[...] quia dirigere non est nisi causare actum". See also Quaest. var., q. 8 (OTh VIII, p. 418): “[...] quod quidem 'dictare' sive 'regulare' non est aliud quam speciali modo illum actum causare [...]."

14 "Alio modo imputabile potest dici quicquid est simpliciter in potestate voluntatis, licet non immediate. Et sic actu alterius potentiae, quem voluntas mediante actu suo volendi potest imperare, ut eliciatur, vel impedire ne eliciatur, est imputabilis voluntati [...]." Scotus, Quodl. 18, n. 10 (Wadding 12, p. 482).

15 "Voluntas autem habet indifferentiam ad contradictoria, \& talem, quod ipsa est sui determinative ad alterum eorum, [...] aliter simul ageret contraria. Propter hoc igitur, quod actus eius sic indifferenter est in eius potestate, licet non nisi supposita intellectione, ideo per se est imputabilis agenti." Scotus, Quodl. 18, n. 9 (Wadding 12, p. 482). "[...] omnes actus qui sunt in voluntate, sunt in potestate voluntatis." Ockham, Quodl. II, q. 17 (OTh IX, p. 188). See also Ockham, Rep. IV, q. 16 (OTh VII, pp. 358-359). For a thorough discussion of the conditions of acts of will in Ockham see Panaccio (2012).

16 See Ockham, Quodl. II, q. 14 (OTh IX, p. 177). See King (1999, pp. 227-244, esp. pp. 227-228).
}

although the other necessary conditions for an act of will are complied with, whereas it is not 'in the power of the intellect' not to produce any act if the conditions for cognition are complied with. For instance, in the very presence of an object, the intellect normally cannot not grasp that object and produce what Ockham calls an act of intuitive cognition, just as a person normally cannot but hear a noise when it is produced in her presence. ${ }^{17}$

Psychologically speaking, that all acts of will are 'in the power of the will' means that the will ultimately controls which acts are elicited and which are not. Whether a person wills to do something in a situation or not depends on herself, that is, her will. It is up to her. She can neither be forced to will something nor impeded from willing something by anything in this world. ${ }^{18}$

By contrast, the production of an act of a physical power can be prevented either by something external to that power, or, as Scotus remarks, "that power can be prevented by its own weakness from executing that act." 19 That an exterior act is mediately in the power of the will means that if a person wills to, say, raise her arm, then she raises her arm; if, however, she fails to raise her arm although she wills to raise it, then the cause of her failure is either due to something external to her physical power of raising her arm (for instance, if her arm is tied to her back), or due to something internal to her physical power (for instance, if she is paralyzed at that side). If she fails to raise her arm although she wills to, the cause of her failure does not lie in her power of will for the reason that no natural cause can prevent her from willing, and thus, attempting to raise her hand.

Exterior acts are voluntary, whereas natural acts are not, since natural acts are not mediately caused by the will. Rather, they have a natural cause. For both Scotus and Ockham, the will is the only cause that is not natural. ${ }^{20}$ For example, digesting one's dinner or hearing a noise are natural acts. ${ }^{21}$ An act is voluntary if it is at least mediately caused and thus mediately in the control of the will. According to Scotus and Ockham, agents can be held accountable only for

\footnotetext{
${ }^{17}$ For Ockham's conception of intuitive cognition, see Panaccio (2004, pp. 5-20) and Schierbaum (2014, pp. 155-174).

18 This account can be found in Ockham. No act of will can "simply be impeded by something created." Ockham, Rep. III, q. 7 (OTh VI, p. 206). God, of course, is always a partial cause of any action. Ibid.

19 Scotus, Quodl. 18, n. 11 (Wadding 12, p. 482).

${ }^{20}$ According to this view, even acts of the intellect have a natural cause insofar as the intellect does not control whether it understands something or not etc. See Hoffmann (2020, pp. 121, 152).

${ }^{21}$ See Anscombe (1957, §7, p. 12). Also, some cognitive acts are 'natural' in this sense, such as acts of intuitive cognition.
} 
the actions that are in their control, at least mediately. ${ }^{22}$ In a similar vein, Aucouturier states that intentional actions are those which "entirely and profoundly engage the responsibility of the agent." 23

Our intentional actions are those we perform on account of an end (see Alvarez 2010, p. 98). For both Scotus and Ockham, that the will elicits its acts only as means to some willed ends is a metaphysical truth about the rational nature of the will. As Ockham states, in general, "the will only acts on account of an end." ${ }^{24}$ Since any act of will presupposes an act of the intellect, it follows that we always act on account of an explicit end. ${ }^{25}$ Therefore, whenever an agent attempts to do something because she wills to, then this is an attempt to act for the sake of or on account of something intended as an end. For Scotus and Ockham, intending something ontologically requires the occurrence of an act of will. ${ }^{26}$

Note that by 'intending' and the corresponding 'intention' I mean the intention in acting. ${ }^{27}$ For example, Anne's intention in boiling water is to make tea. Making tea is Anne's

\footnotetext{
${ }^{22}$ Put differently, that an act is in one's control means that one could have not elicited that act and thus, could have acted otherwise. It is a strong, voluntarist intuition that we are (morally) responsible for an act only if we could have acted otherwise. In contemporary philosophy, there is a strong, compatibilist tendency against this intuition that moral responsibility presupposes the possibility to do otherwise. See Frankfurt (1969) and Davidson (1980).

${ }^{23}$ See Aucouturier (2018, p. 266). See also Anscombe (1957, § 49, p. 89).

24 Ockham, Ord. I, q. 10 (OTh I, p. 291).

25 According to Anscombe, it is strange to say that we always act with an explicit and definite end 'in view'. See Anscombe (1957, $\S 21$, pp. 33-34). There seems to be a further difficulty implied by Ockham's radical view that the will can set up literally anything as an ultimate end. For presentation and discussion of this point, see Hoffmann (2020, pp. 154-158). The difficulty is that it seems unclear what kind of act of the intellect could precede this volitional act of setting up something as an ultimate end. As I see it, an answer could start from the fact that the will, being a cause of its own acts, merely needs some representation of some object in order to elicit an act. The point is that in some basic, metaphysical sense, everything which exists (or can exist) is good in the sense of being created (or being able to be created) by God. Further, Ockham seems to think that everything which is good in this fundamental sense can also be willed as an end. On this point, see Schierbaum (2017, pp. 134-136). Of course, such a choice would still be objectionable in that it would lack a good reason. This, however, is a different problem.

26 These acts of will can have a complex structure. I discuss this in Sect. 3.

27 According to Anscombe, there are three cases in which we apply a concept of intention: (i) in the expression of an intention about the future, (ii) in the case of intentional action, or more precisely, in the intention of doing something, and (iii) in the intention in acting or doing something. For the threefold distinction concerning the term 'intention', see Anscombe (1957, §§ 16, 20, 26, 30, pp. 24, 30-31, 45-47, 53-54). See also Aucouturier's presentation and discussion of this threefold distinction. Aucouturier (2018, pp. 21-24).
}

intention in boiling water. ${ }^{28}$ The intention in doing is the end at which the action is directed or on account of which the action is performed. The same point is also made by Alvarez:

[...] our goals in acting are precisely what our actions tend towards - that is, our intentions in acting: goals are intended ends for the sake of which action is undertaken. In other words, our goals are our intentions in acting. (Alvarez 2010, p. 97)

Raising one's arm can be, but bidding at an auction (by raising one's arm) is always an intentional action. Likewise, pressing the keys of a piano with one's fingers can be, but playing the Aria of Bach's Goldberg Variations on the piano is always an intentional action.

Scotus would conceive of bidding at an auction (by raising one's arm) and playing Bach (by pressing the piano keys) as exterior acts. Such exterior acts correspond to intentional actions. By contrast, a natural act, that is, an act of a power which is not mediately caused by the will does not correspond to an intentional action.

To set the stage for the discussion of the individuation of moral intentional action, I will present the problem of the moral value of interior and exterior acts, since the matter was discussed in this context. The controversial issue is whether an exterior act has a 'proper' moral value, that is, a value of its own, like the interior act, or not.

\section{The Moral Goodness of Interior and Exterior Acts}

The aim of this section is to clarify Scotus's and Ockham's accounts of the moral goodness of interior and of exterior acts. The two medieval authors agree at least that moral goodness is an intrinsic property of interior acts, although their accounts differ in some important respects. ${ }^{29}$

In the context of this paper, I use 'intrinsic' and 'extrinsic' as follows. That $F$ is an intrinsic property of a thing $a$ means that the loss of $F$ affects the identity of $a$ : if $a$ loses its property $F$, then $a$ is no longer the same. By contrast, if a property $G$ is only an extrinsic property of a thing $a$, then the loss of $G$ does not affect the identity of $a$ : if $a$ loses its property $G$, then $a$ is still the same. ${ }^{30}$ Let us start with the moral goodness of interior acts. Scotus writes:

\footnotetext{
28 The example is Aucouturier's. Ibid.

${ }^{29}$ For Scotus's understanding of moral goodness, see Williams (1998, pp. 162-181); Williams (2000, pp. 169-202); Williams (2003, pp. 335-342); Ingham (2000, pp. 173-195); Ingham and Dreyer (2004, pp. 173-200); Wolter (2003, pp. 313-356).

${ }^{30}$ See Ockham, De connex., q. 7, art. 1 (OTh VIII, pp. 327-329).
} 
[...] the moral goodness of an act is the completeness (integritas) of all the features that the agent's right reason judges ought to characterize the act or the agent in so acting. ${ }^{31}$

Scotus notably stresses the 'completeness' of an act: an act is morally good if it has all of the required features. These features include factors such as the intended end, time and place, and also the 'mode' or way of acting. Scotus, like Ockham, calls these factors 'circumstances'. ${ }^{32}$ That these features include the 'mode' of acting explains why Scotus speaks of the features as characterizing the act $o r$ the agent in so acting. As far as I can see, Scotus here refers to his preceding discussion of the way rational agents, that is, agents with the power of intellect and will, can act as opposed to agents lacking the power of the intellect and will. ${ }^{33}$ Only rational agents can act on the basis of their judgment concerning the moral quality of the intended act. They also should adjust their acts to their judgment. Scotus also calls the judgment of right reason an intrinsic rule of rectitude of the agent's own acts. ${ }^{34}$ Thus, the 'mode' of acting can be taken to characterize the rational agent as acting knowingly and explicitly on the basis of his judgment concerning the moral quality of the intended act. The crucial point is that the judgment concerns all the required features. Unlike Ockham, Scotus does not conceive of the end as the principal object of an act of will. ${ }^{35}$

\footnotetext{
31 "De primo, bonitas moralis actus est integritas eorum quae recta ratio operantis iudicat debere ipsi actui convenire vel ipsi agenti debere in suo actu convenire." Scotus, Quodl. 18, n. 3 (Wadding 12, p. 475).

${ }^{32}$ For an overview of the 'circumstances' in the medieval tradition see Gründel (1963).

33 See Scotus, Quodl. 18, nn. 3 and 4 (Wadding 12, p. 476). According to Hoffmann, however, it is also possible that Scotus refers to the traditional doctrine that for an action to be morally good, it is not sufficient that what is done is good, but that it is also "well" done, that is, in the right way. Perhaps Scotus here refers to Aristotle's Nicomachean Ethics III, 1. In other contexts, however, Scotus also refers to whether an action is performed freely (and rationally) or merely naturally, as in $O r d$. I, d. 1, p. 2, q. 2, n. 80 (Vat. II, p. 60); Ord. I, d. 10, q. un., n. 44 (Vat. IV, p. 358); Ord. II, d. 39, q. 2, n. 25 (Vat. VIII, p. 464). This latter sense would fit my reading. Hoffmann, however, does not think that Scotus has this latter sense in mind in the Quodl. 18. All in all, it is rather unclear what exactly Scotus refers to here. (Private communication)

34 "Sed non sufficit ad illam (bonitatem moralem) quod in agente sit potentia iudicativa de convenientia sui actus, sed oportet, quod actu recte iudicet et secundum illud iudicium actus fiat." Scotus, Quodl. 18, n. 4 (Wadding 12, p. 476).

35 According to Osborne, Scotus separates end and object of a moral act due to his understanding of praxis which is concerned with the suitability of an act for an agent, and not with an end as an end. See Osborne (2007, p. 124).
}

Moral goodness is further classified as a kind of accidental goodness, as opposed to essential goodness. ${ }^{36}$ There are two kinds of accidental goodness, namely (a) the "completeness of a thing's suitability, or a thing's complete suitability, to some other thing to which it ought to be suitable" and (b) "the (complete) suitability of some other thing to it." ${ }^{37}$ This is a difference in perspective. Accidental goodness concerns the relation of things which are good to or for other things and in this sense, are perfections of other things. Things perfecting other things are good for other things, but are not good in themselves, whereas the things perfected are good in themselves.

The first kind of accidental goodness concerns the thing that perfects another thing insofar as it is (a) suitable for another thing. An example would be health: to be healthy is good for human beings, because it is suitable for them, but it is not good in itself. The second kind concerns the thing perfected insofar as (b) it has a perfecting feature. Scotus presents Augustine's example of a human face: a face that has all the features that are suitable to it, such as being wellproportioned and cheerful, is good in virtue of having all the features suitable to it. Morally good acts are good in this second sense. As indicated, the features in virtue of which an act is morally good are the end on account of which that act is elicited, the mode of acting, and time and place. ${ }^{38}$ To be exact, it seems that an act of will needs to be elicited in the right relation to these factors, that is, on account of an appropriate end, at the appropriate time and place, and on the basis of a judgment concerning the moral quality of the intended act. An act of willing such as giving alms is good in general because its object is suitable. Whether a particular act of willing to give alms is morally good depends on its being performed on account of the appropriate end, at the appropriate time and place, and on the basis of a judgment, that is, knowingly. Although willing to give alms never is bad in and of itself, it can be morally better or worse depending on the circumstances. ${ }^{39}$

For Scotus, the most relevant feature is the act's relation to right reason. For an interior act to be morally good it is required that it complies with all the features that the agent judges that the act ought to comply with and because the agent judges that the act ought to comply with them. Thus:

Moral goodness: An interior act A of a person is morally good if and only if A has all the features that the person's right reason judges ought to characterize A.

\footnotetext{
${ }^{36}$ See Scotus, Quodl. 18, n. 3 (Wadding 12, p. 475).

37 " [...] est integritas convenientiae vel integra convenientia eius quod debet sibi convenire, vel alterius sibi." Ibid.

38 See Scotus, Quodl. 18, n. 6 (Wadding 12, p. 479).

39 See ibid.
} 
The features of end, mode of acting, time and place are features of the interior act of will in the first place, not of the ensuing exterior act. This is where double intentionality comes into play. The agent, by means of this act of willing, not merely intends something as an end, but also intends it as an end in light of his judgment that he ought to intend the end in these circumstances and in this particular way. In the terminology of double intentionality, this is what constitutes the difference between an interior act of willing and a morally good interior act of willing, namely the order of the interior act and the normative judgment that this interior act ought to be elicited.

How does Ockham conceive of the moral goodness of interior acts? Ockham agrees that being morally good is an intrinsic property of an interior act. He even provides an argument why there have to be intrinsically good acts. ${ }^{40} \mathrm{In}$ his view, however, the end is the principal object of the interior act, since it metaphysically determines the act of will in the first place. Also, the pleasure of attaining the end is what is principally intended by such an interior act. ${ }^{41} \mathrm{His}$ account crucially differs from Scotus's in that Ockham conceives of all circumstances, including the end and also the judgment of right reason, as partial objects of the interior act, not of the exterior act. ${ }^{42}$

The objects determine the interior act as to its identity: if only one of the objects changes, then the act is no longer the same.$^{43}$ Ockham has a metaphysical reason for conceiving of all circumstances as partial objects of the interior act. This reason relates to the issue of imputability and moral responsibility. Ockham's point is that the latter presupposes that the act for which an agent can be morally responsible in the first place has to be in the agent's control, that is, in his power. If an interior act could remain the same while one of the required circumstances changes, then a morally bad, interior

\footnotetext{
40 The upshot of his argument is that there is the threat of an infinite regress if there were only extrinsically good acts. His point is that extrinsically good acts are acts that can also be vicious. Also, extrinsically good acts are made good by another act. Now, this other act is either extrinsically good too, in which case there has to be another act making it good, or this other act is intrinsically good. His point is that either there are intrinsically good acts or for every extrinsically good act or there is an infinity of extrinsically good acts, and the latter option is absurd. See Ockham, De connex., q. 7, art. 1 (OTh VIII, pp. 327-328).

41 "[...] dico quod finis est obiectum principale actus virtuosi intrinsece, quia dilectio finis principaliter intenditur [...]." Ockham, Quodl. III, q. 16 (OTh IX, p. 267). For discussions of Ockham's ethical account see McCord Adams (1998, 1999); Freppert (1988); Holopainen (1991); Müller (2000).

42 See Ockham, Rep. III, q. 11 (OTh VI, p. 382).

43 "Actus autem intrinsece virtuosus variatur propter variationem cuiuscumque circumstantiae, quia variato obiecto non potest esse idem actus propter transitum a contradictorio in contradictorium." Ockham, Quodl. III, q. 16 (OTh IX, p. 266).
}

act could be made morally good by the occurrence of something that is not in the agent's power, such as a judgment of right reason. ${ }^{44}$ For instance, the morally rather dubious act of willing to donate to church just for the purpose of obtaining a tax break could be rendered morally good by the judgment that one ought to donate to church for the love of God; since, however, one's judgments are not in one's control, one's acts of will could be rendered morally good by something one cannot control. This would be disastrous, Ockham argues, for in that case someone not worthy of eternal life could become worthy of it (and conversely) by something that is not in his power. ${ }^{45}$ According to Scotus and Ockham, the point is that rational agents, as opposed to natural agents, are able - and obligated - to actively and freely adjust their acts of will to their judgments of right reason: this is what makes interior acts morally good. Therefore, it is possible to interpret Ockham's account in such a way that the agent, by means of his morally good interior act of willing, not merely intends something as an end, but also intends it as an end in light of his judgment that he ought to intend the end in these circumstances and in this particular way. In this respect, Ockham's and Scotus's accounts differ only regarding their conception of circumstances, but not with respect to the fact that their accounts of morally good interior acts can be interpreted in terms of double intentionality.

The structure of an interior act is quite complex, since it includes a multitude of partial objects (Ockham) or at least a multitude of relations to factors such as the end, time, and place (Scotus). Willing to do what one ought to do also implies a kind of multiple intentionality insofar as the agent has to be directed at a multitude of factors (end, time, place) that are not ordered or structured in the way intending something as an end and intending it as an end in light of a normative judgment are. ${ }^{46}$ This complexity corresponds to the specification of content. The content of the act of will, that is, what one wills to do, has to be sufficiently specified in order to actually cause the attempt of doing what one wills to do. For instance, willing to give alms, by itself, is not specific enough to make the agent actually attempt to give alms.

With respect to Ockham's account, one could worry how one act can have a multitude of objects. Ockham resorts to a kind of constitutive compositionality of acts. All acts

\footnotetext{
${ }^{44}$ See Ockham, Quodl. III, q. 16 (OTh IX, pp. 264-265). Acts of the intellect are not in the control of the agent. See above, Sect. 2.

45 See ibid.

${ }^{46}$ It is to be emphasized that this multiple intentionality is a feature of complexly willing what one ought to do. Simpler acts of willing, willing to eat an apple for instance, only presuppose some act of the intellect, that is, some representation of an apple. However, simply willing to eat an apple does not imply willing this at the 'right time' and the 'right place'. For discussion, see Panaccio (2012, p. 83); see also Ockham, Rep. II, q. 20 (OTh V, pp. 441-442).
} 
are what he calls either incomplex or complex. ${ }^{47}$ Roughly, incomplex acts, such as intuitively grasping particular things, correspond to non-propositional acts, and complex acts, such as of judging that $p$, correspond to propositional acts. As Panaccio points out, less attention is paid to the fact that Ockham also makes this distinction regarding incomplex and complex acts of will. ${ }^{48}$

Generally, incomplex acts have particular 'incomplex' things as their objects, whereas the object of complex acts is itself complex. According to Ockham, any complex act is constituted by its incomplex parts. Thus, any complex act conceptually or logically presupposes some incomplex act or acts as its parts. ${ }^{49}$ Incomplex acts are prior insofar as it is impossible that there is a complex act without incomplex constituents. For instance, one cannot think that apples are delicious without entertaining the thought's constituent parts ('apples', 'delicious'). Ockham turns all the aspects one has to consider in order to attempt to do what one wills into causally efficient partial objects of the interior act of will. Recall that any act of will presupposes an act of the intellect. This act is a partial cause of the act of will. ${ }^{50}$ Thus, one act of will can have a multitude of objects insofar as the content of what one wills is represented by a complex, cognitive act to the agent. Without a representation of what one wills to do, giving alms to the beggar in front of the supermarket for instance, one cannot will, and thus attempt to give alms to the beggar in front of the supermarket. This representation corresponds to the description of the intentional action. ${ }^{51}$

Against this backdrop, I now turn to the moral quality of exterior acts. Scotus writes:

[...] it can be said that an exterior act - that is, a commanded act - has its own moral goodness, distinct from that of the interior, elicited act [...]. We established that the moral goodness of an act is the completeness of those features that the agent's right reason dictates should characterize the act. Now the completeness of the features that ought to characterize an interior act according to right reason is distinct from the completeness of the features that ought to char-

\footnotetext{
47 Ockham distinguishes between different sorts of incomplex and complex acts of the intellect in his Ordinatio. See Ord. I, prol., q. 10 (OTh I, pp. 285-290).

48 See Panaccio (2012, p. 81). For discussion of incomplex and complex acts of will in Ockham, see Schierbaum (2017).

49 See Ockham, Ord. I, prol., q.1 (OTh I, p. 21).

50 " [...] potest concedi quod intellectus est prior voluntate, quia actus intelligendi est causa efficiens partialis respectu actus volendi, et potest esse naturaliter sine actu volendi sed non e converso." Ockham, Rep. II, q. 20 (OTh V, pp. 441-442).

51 See Sect. 1.
}

acterize an exterior act. Therefore, there is a distinct moral goodness $[\ldots] .{ }^{52}$

Scotus holds that an exterior act has its proper moral goodness insofar as the set of features of morally good exterior acts and the set of features of morally good interior acts are distinct (in kind): an exterior act is morally good insofar as it is caused by a morally good interior act, that is, an act that has all the required features enumerated above.

Ockham agrees that an exterior act can be called 'morally good' insofar as the interior act that mediately causes them is morally good. This, however, does not make for a proper kind of moral quality. As Ockham puts it in reply to Scotus:

[...] I reply that it is not the exterior act that must have an integrity of circumstances in accord with right reason, but only the interior act. On the contrary, the exterior act needs only to be elicited effectively by a good interior act, and it has no other sort of integrity. ${ }^{53}$

Ockham's point is that an exterior act is only extrinsically good. This means that the exterior act can change its moral quality while remaining the same act.

The crucial difference between Scotus's and Ockham's accounts is that, for Scotus, both interior and exterior acts can be intrinsically good, in their respective ways, whereas for Ockham only interior acts can be intrinsically good, while exterior acts can only be extrinsically good. It should become clear in the next section that this disagreement as to the moral quality of exterior acts has crucial consequences with respect to how exterior acts are thought to be individuated by Scotus and Ockham respectively. Scotus would agree that an exterior act can be individuated by its cause, namely the interior act. After all, that an exterior act is morally good just means that it is caused by a morally good interior act. What is responsible for the proper moral quality of the exterior act, however, can also serve to individuate the exterior act, for if the interior act changes, then the exterior act changes as well. Ockham denies this. I now turn to the problematic case of the change of intention.

\footnotetext{
52 “[...] potest dici, quod actus exterior, scilicet imperatus, habet bonitatem moralem propriam aliquam aliam, quam actus interior elicitus; [...] habetur, quod bonitas moralis est integritas eorum, quae secundum rectam rationem operantis dicuntur debere convenire ipsi actui. Est autem alia integritas eorum, quae secundum dictamen rectae rationis debet convenire actui interiori, \& eorum, quae actui exteriori igitur \& alia bonitas moralis [...]." Scotus, Quodl. 18, n. 12 (Wadding 12, p. 484). See Osborne (2007, pp. 122-129).

53 “....] dico quod actui exteriori secundum rectam rationem non debet aliqua integritas circumstantiarum competere, sed tantum actui interiori. Sed actus exterior tantum debet elicit effective ab actu bono interiore, sed aliam intergritatem non habet." Ockham, Quodl. I, q. 20 (OTh IX, p. 105). The translation is Freddoso's and Kelley's (1991, p. 90). Note that Freddoso and Kelley translate "integritas" as "integrity", not as "completeness", as Osborne does with Scotus's text.
} 


\section{The Change of Intention}

Again, Ockham thinks that the moral quality of interior acts is an intrinsic property insofar as interior acts are causally determined by their partial objects (the end, time, place, judgement of right reason) taken together. By contrast, the moral quality of exterior acts is only an extrinsic property; that an exterior act is morally good (or bad) means that it is caused by a morally good (or bad) interior act.

The problem is that Ockham can be taken to hold that an exterior act is not individuated by its cause. An exterior act can remain numerically the same although its cause changes. That is, we are dealing here with numerical identity, and thus, tokens of actions. Ockham gives the example of a person on her way to church with the intention of praising God. ${ }^{54}$ Recall that the intention in action is nothing but the intended end. It is worth quoting the passage in its entirety:

The principal object of an act of the will is the object the pleasure of which is principally intended; the end is of this sort. But still, if I call this object 'principal', which is the common object, just to distinguish it from the circumstances, the exterior act is thus the principal object because the exterior act is the common object, since it can remain the same with respect to many acts of will. For instance, if I want to go to church for the grace of God first, then 'going to church' is the common object, and 'grace' the circumstance. But if later I want to go [to church] at a determinate time, then the act of will changes, and the act of walking can remain the same. If, hitherto, I want to go [to church], for the grace of God, at a determinate time and according to right reason, and all of this while I am walking, this exterior act [of walking] always remains the same, but the act of will changes. And therefore it [the exterior act], is called the common object, because it can be the object of many acts of will, and can remain the same with and without the circumstances. And from this it becomes clear that whenever any circumstance changes with respect to an act of will, then the act of will changes, although not the exterior [act]. ${ }^{55}$

\footnotetext{
${ }_{54}$ This is one of Ockham's favorite examples. See Quodl. I, q. 20 (OTh IX, p. 101); De connex., q. 7, art. 1 (OTh VIII, p. 328). Note that Ockham there also discusses cases of change of moral quality.

55 “....] illud est obiectum principale actus voluntatis cuius dilectio principaliter intenditur; huiusmodi est finis. Sed tamen vocando illud obiectum principale quod est obiectum commune prout distinguitur contra circumstantias, sic actus exterior est obiectum principale quia actus exterior est obiectum commune, quia potest idem manere respectu multorum actuum voluntatis. Puta, si primo velim ire ad ecclesiam pro honore Dei, hoc 'ambulare ad ecclesiam' est obiectum commune, et 'honor' circumstantia. Sed si post velim ire tempore statuto, tunc variatur actus voluntatis, et potest manere idem actus ambulandi. Si adhuc velim ire propter honorem Dei tempore statuto
}

Suppose that Peter is on his way to church in order to attend service. He primarily considers this as an obligation towards God. Peter leaves the car behind and walks. Now, while walking, he realizes that today's service is special since it is Easter service, thus he now intends to attend Easter service. ${ }^{56}$ This change in the description does not seem dramatic. Still, the interior act of will changes, since one partial object changes. In the example, partial objects are added consecutively. The end, however, is always the same, namely to praise God (or to do one's duty toward God). ${ }^{57}$ As stated earlier, Ockham conceives of the end as the principal object of an interior act. ${ }^{58}$ All in all, Peter elicits three interior acts, namely:

(1) The act of willing to go to church in order to praise God.

(2) The act of willing to go to church in order to praise God, in church, during Easter service.

(3) The act of willing to go to church in order to praise God, in church, during Easter service, and "according to right reason" (i.e., for the reason that it is a duty).

The exterior act, that is, the act of walking to church, remains unaffected by the multiple instances of changing of its cause. It is the same act throughout. ${ }^{59}$

Does the act of walking to church remain the same because the end remains the same throughout? Is the intended end sufficient to individuate the exterior act as an act, not simply of walking, but as an act of walking to church? The answer is 'no', since not even the end, like any of the circumstantial factors, is a partial object of the exterior act. Ockham explicates further:

\section{Footnote 55 (continued)}

et secundum rectam rationem, et hoc semper in ambulando, semper iste actus exterior manet idem, tamen actus volendi variatur. Et ideo dicitur obiectum commune, quia potest esse obiectum multorum actuum volendi, et potest manere idem cum circumstantiis et sine circumstantiis. Et ex hoc patet quod quandocumque variatur circumstantia aliqua respectu actus volendi, variatur ipse actus voluntatis licet non exterior." Ockham, Rep. III, q. 9 (OTh VI, pp. 382-383). (Italics mine).

${ }^{56}$ I tried to render the temporal factor ("tempore statuto") in this way.

57 This is how I try to render the nominal expression "pro honore Dei". In other passages, Ockham uses the expression "propter ..." See Ockham, Rep. III, q. 9 (OTh VI, pp. 381-382); De connex., q. 7, art. 1 (OTh VIII, p. 328); De connex., q. 7, art. 4, dub. 8 (OTh VIII, p. 395).

58 See fn. 41.

59 This implies that acts can be extended in time. Scotus seems to deny that acts can be extended in time. See Scotus, Quodl. 18, n. 16 (Wadding 12, p. 486). 
But with respect to the exterior act, [the circumstances] are not partial objects, which act is called a common object, because the act of praying or of walking or any such act neither has time nor place nor right reason nor the end as an object, as the other; the act of eating, for instance, has food as its object, the act of walking, the road. And the other circumstances do not do anything to this act but to stand next to it, that is, they surround that act without any causality. ${ }^{60}$

Circumstances are causally inefficient with respect to the exterior act, because they are not partial objects of the exterior act. The object of an act is that at which the agent is directed, if the act is cognitive or conative. In contemporary discussions, the intentional relation of being directed at something only concerns cognitive or conative acts. ${ }^{61}$ According to Ockham, the intentional relation of being - cognitively or conatively - directed at something is cashed out, ontologically, in terms of efficient causality. The object of a cognitive or conative act is also an efficient cause of that act.

With respect to acts of physical powers, however, things are different. This becomes clear from the example in the quoted passage. If Peter eats a sandwich, then the object of his act of eating is the sandwich. Peter's act of eating is individuated by its object, namely, the sandwich. Eating a sandwich is not the same as eating ice cream. Still, Peter's eating is not 'directed at' or 'about' the sandwich, since only conative or cognitive acts are intentional in this sense. Rather, the interior act of willing to eat a sandwich which caused the act of eating is directed at the sandwich. That is, the cause of the act of eating is not the same as its object. Interior and exterior acts are individuated by their objects. Yet, they differ in that the cause of an exterior act is not the same as its object, whereas the cause of an interior act just is the same as its object: the crucial difference between interior and exterior acts is that interior acts are intentional in that they are directed at their object, whereas exterior acts are not intentional. The point, again, is that Ockham accounts for the intentional relation of being directed at something in terms of efficient causality.

The surprising result is that the intended end on account of which an exterior act is performed does not make any

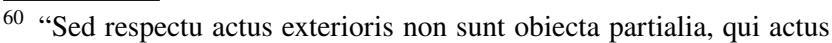
dicitur obiectum commune, quia actus orandi vel ambulandi vel aliquis talis exterior actus non habet tempus pro obiecto nec locum nec rectam rationem nec finem, sicut alius, puta actus comedendi habet cibum pro obiecto, actus ambulandi, viam. Et aliae circumstantiae quantum ad istum actum nihil faciunt nisi stant iuxta, id est, circumstant illum actum sine aliqua causalitate." Ockham, Rep. III, q. 9 (OTh VI, p. 382). (Italics mine).

${ }^{61}$ Intentionality (i.e., being directed at something) is, as the slogan goes, the mark of the mental. For discussion, see Crane (1998).
}

difference as to the numerical identity of the exterior act. Whether Peter intends to go to church or to work does not affect the numerical identity of his act of walking, if, while walking, he changes his intention. In other words, the exterior act, thus conceived, is distinct from the intentional action of doing something on account of an end; the exterior act is nothing but the 'natural' act of bodily movement. In fact, according to some interpreters, Ockham deviates from both Scotus and the tradition in that he does not distinguish between the exterior and the natural act (Osborne 2007, p. 130). Therefore, the intentional action of going to church is not the same as the exterior act of walking, taken by itself. Intentionality leaves its mark in language. Going somewhere is not the same as simply walking, since the former, unlike the latter, is inherently goal-directed. In Ockham's view, an intentional action seems to be a causally connected composite of an interior act and a physical act of bodily movement, that is, an exterior act. Crucially, the intentionality of the action is exclusively due to the intentionality of the interior act of willing, since, in and of themselves, physical acts of bodily movement are not intentional. Similarly, the moral quality of the intentional action, that is, of the causally connected composite of the interior and the exterior act, is only due to the moral quality of the interior act. As we saw in Sect. 3, the interior act is morally good because of its double intentionality: the act is not only directed at something as an end, but is directed at something as an end in light of the normative judgment of right reason, whereas the exterior act is morally good only insofar as it is caused by the interior act.

\section{Conclusion}

My main interpretative task in this paper was to clarify how Scotus and Ockham explain moral intentional action in terms of the role and involvement of interior and exterior acts respectively. It became clear that both authors account for the moral quality of interior acts by means of double intentionality. They agree in general that moral goodness is an intrinsic property of interior acts. As a consequence, they also agree that morally good interior acts are not only directed at something as an end, but rather, at something as an end in light of the normative judgment of right reason. Ockham and Scotus only differ in their conception of the circumstances involved. Ockham turns all circumstances into causally efficient partial objects of the interior act, whereas Scotus does not. They agree, however, that interior acts can be individuated by means of their circumstances.

By contrast, Scotus and Ockham disagree as to the moral goodness of exterior acts: Scotus holds that moral goodness is also an intrinsic property of exterior acts, whereas Ockham does not. Their disagreement has crucial consequences for the individuation of exterior acts and, hence, 
for the respective account of intentional action. According to Scotus, an exterior act can be individuated by means of its cause, that is, an interior act, whereas Ockham denies this; he agrees, though, that an exterior act is caused by an interior act. According to Ockham, however, an exterior act can remain the same although its cause, that is, the interior act, changes. As a result, it can be said that on Scotus's account, an intentional action such as going to church corresponds to an exterior act, since the act of going to church is an act of moving one's body on account of an end. According to Ockham's account, however, the intentional action of going to church does not correspond to the exterior act, since on his view the exterior act is nothing but the physical act of bodily movement. Rather, the intentional action of going to church corresponds to both the causally connected composite of an interior act of willing to go to church and the physical act of walking. Furthermore, Scotus accounts for the moral quality of an intentional action in terms of the exterior act's proper moral quality, whereas Ockham accounts for the moral quality of an intentional action in terms of the moral quality of the interior act.

In general, it seems that Scotus's account is closer to the common, contemporary understanding of intentional action, i.e., doing something on account of an end, than Ockham's. ${ }^{62}$ What seems odd from this contemporary perspective with respect to Ockham's approach is that the intentionality of an action such as that of going to church seems to be only a matter of the interior act causing the bodily movement, but not of moving one's body intentionally, that is, on account of an intended end, since the act of moving is not individuated by the intention in acting, that is, the intended end. But incompatibility with contemporary views on intentional action alone is not sufficient to dismiss Ockham's account of intentional action. Rather, the results of this paper should raise the reader's awareness for the range of possibilities concerning the conceptions of intentionality and of intentional action in the history of philosophy without judging them prematurely simply because these possibilities do not fit within the possibilities of contemporary, Anscombian approaches to intentional action.

Acknowledgements I would like to thank Jörn Müller, Dominik Perler, and the three editors Michela Summa, Martin Klein, and Philipp Schmidt for helpful comments on earlier drafts of this paper. I also thank the anonymous reviewers for their comments and suggestions. All remaining faults and incongruities are mine.

Funding Open Access funding enabled and organized by Projekt DEAL. Work on this paper has been generously funded by the Deutsche Forschungsgemeinschaft (DFG, German Research Foundation), Project No. 417359636

$\overline{62 \text { See Sect. } 1 .}$
Open Access This article is licensed under a Creative Commons Attribution 4.0 International License, which permits use, sharing, adaptation, distribution and reproduction in any medium or format, as long as you give appropriate credit to the original author(s) and the source, provide a link to the Creative Commons licence, and indicate if changes were made. The images or other third party material in this article are included in the article's Creative Commons licence, unless indicated otherwise in a credit line to the material. If material is not included in the article's Creative Commons licence and your intended use is not permitted by statutory regulation or exceeds the permitted use, you will need to obtain permission directly from the copyright holder. To view a copy of this licence, visit http://creativecommons.org/licenses/by/4.0/.

\section{References}

Alvarez M (2010) Kinds of reasons: an essay in the philosophy of action. Oxford University Press, Oxford

Anscombe GEM (1957) Intention. Blackwell, London

Anscombe GEM (1981) The intentionality of sensation. Metaphysics and the philosophy of mind: collected papers, vol II. Blackwell, Oxford, pp 3-20

Antognazza MR (2015) The benefit to philosophy of the study of its history. Br J Hist Philos 23:161-184

Aucouturier V (2018) L'intention en action. Vrin, Paris

Brower-Toland S (2007) Intuition, externalism, and direct reference in Ockham. Hist Philos Q 24(4):317-335

Choi Ph (2016) Ockham's weak externalism. Br J Hist Philos 24(6):1075-1096

Crane T (1998) Intentionality as the mark of the mental. R Inst Philos Suppl 43:229-251

Davidson D (1963) Actions, reasons, and causes. J Philos 60(23):685-700

Davidson D (1980) Freedom to act: essays on actions and events. Oxford University Press, Oxford

Frankfurt H (1969) Alternate possibilities and moral responsibility. J Philos 66:829-883

Freddoso A, Kelley FA (1991) William Ockham: Quodlibetal questions, vol 1. Yale University Press, New Haven

Freppert L (1988) The basis of morality according to William Ockham. Franciscan Herald Press, Chicago

Goldman AI (2013) The individuation of action. Joint ventures: mindreading, mirroring, and embodied cognition. Oxford University Press, Oxford, pp 259-272

Gründel J (1963) Die Lehre von den Umständen der menschlichen Handlung im Mittelalter. Aschendorff, Münster

Hoffmann T (2020) Free will and the Rebel Angels in medieval philosophy. Cambridge University Press, Cambridge

Holopainen TM (1991) William Ockham's theory of the foundations of ethics. Luther-Agricola Society, Helsinki

Hornsby J (1980) Actions. Routledge and Kegan Paul, London

Ingham MB (2000) Duns Scotus, morality and happiness: a reply to Thomas Williams. Am Catholic Philos Q 74:173-195

Ingham MB, Dreyer M (2004) The philosophical vision of John Duns Scotus: an introduction. The Catholic University of America Press, Washington, DC

John Duns Scotus (1950-2013) In: Commissio Scotistica (ed) Opera Omnia (= Vat.). Typis Polyglottis, Vatican

John Duns Scotus (1986) In: Wadding L (ed) Opera omnia (= Wadding). Durand, Lyon 1639; reprint: Georg Olms, Hildesheim

King P (2015) Thinking about things: singular thought in the middle ages. In: Klima G (ed) Intentionality, cognition, and mental representation in the middle ages. Fordham University Press, New York, pp 104-121 
King P (1999) Ockham's ethical theory. In: Spade PV (ed) The Cambridge companion to Ockham. Cambridge University Press, Cambridge, pp 227-244

Lagerlund H (2015) Singular terms and vague concepts in late medieval mental language theory: Or the decline and fall of mental language. In: Klima G (ed) Intentionality, cognition, and mental representation in the middle ages. Fordham University Press, New York, pp 122-140

Lukasiewicz J, Anscombe GEM, Popper K (1953) Symposium: the principle of individuation, proceedings of the Aristotelian Society. Suppl Vol 28:69-120

Mackie D (2003) The individuation of actions. Philos Q 47:38-54

McCord AM (1998) Ockham on final causality: muddying the waters. Franciscan Stud 56(1):1-46

McCord AM (1999) Ockham on will, nature, and morality. In: Spade VP (ed) The Cambridge companion to Ockham. Cambridge University Press, Cambridge, pp 245-272

Müller S (2000) Handeln in einer kontingenten Welt: Zu Begriff und Bedeutung der rechten Vernunft (recta ratio) bei Wilhelm von Ockham. Francke, Tübingen

Normore C (2003) Burge, Descartes, and us. In: Hahn M, Ramberg B (eds) Reflection and replies: essays on the philosophy of Tyler Burge. The MIT Press, Cambridge, pp 1-14

Osborne ThM (2007) The separation of the interior and the exterior acts in Scotus and Ockham. Mediaev Stud 69:111-139

Panaccio C (2004) Ockham on concepts. Ashgate, Aldershot

Panaccio C (2010) Intuition and causality: Ockham's externalism revisited. Quaestio 10:241-253

Panaccio C (2015) Ockham's externalism. In: Klima G (ed) Intentionality, cognition, and mental representation in the middle ages. Fordham University Press, New York, pp 166-185

Panaccio C (2012) Intellections and volitions in Ockham's nominalism. In: Pickavé M, Shapiro L (eds) Emotion and cognitive life in medieval and early modern philosophy. Oxford University Press, Oxford, pp 75-93

Perler D (2018) The alienation effect in the historiography of philosophy. In: van Ackeren M (ed) What does philosophy owe to its history? Historical and systematic perspectives. Oxford University Press, Oxford, pp 140-154

Schierbaum S (2014) Ockham on the possibility of self-knowledge: knowing acts without knowing subjects. Vivarium 52(3-4):220-240

Schierbaum S (2017) Intellections and volitions: Ockham's voluntarism reconsidered. In: Pelletier J, Roques M (eds) The language of thought in late medieval philosophy. Springer, Dordrecht, pp $125-143$

Thomson JJ (1971) Individuating actions. J Philos 68(21):774-781

William of Ockham (1967-1988) In: Gál G et al (ed) Opera Philosophica et Theologica ( $=\mathrm{OPh}$ and OTh). The Franciscan Institute, St. Bonaventure

Williams Th (1998) The unmitigated Scotus. Archiv Gesch Philos $80: 162-181$

Williams Th (2000) A most methodical lover? On Scotus's arbitrary creator. J Hist Philos 38:169-202

Williams Th (2003) From metaethics to action theory. In: Williams Th (ed) The Cambridge companion to Duns Scotus. Cambridge University Press, Cambridge, pp 332-351

Williams Th (ed) (2017) John Duns Scotus: selected writings on ethics. Oxford University Press, Oxford

Wolter AB (2003) The unshredded Scotus: a response to Thomas Williams. Am Cathol Philos Q 77:313-356

Publisher's Note Springer Nature remains neutral with regard to jurisdictional claims in published maps and institutional affiliations. 